\title{
無電解ニッケルめっき老化液処理への還元晶析法の適用 一反応挙動に対する種晶比表面積の影響一
}

\author{
堀川健*, 平沢泉** \\ ${ }^{*}$ 日本化学工業(侏（干136-8515 東京都江東区亀戸 9-11-1） \\ **早稲田大学 理工学部（广169-8555 東京都新宿区大久保 3-4-1）
}

\section{Application of Reduction Crystallization to the Treatment of Electroless Nickel Plating Wastewater - The Effect of Specific Surface Area of Seed Crystals on the Reaction Behavior-}

\author{
Ken HORIKAWA* and Izumi HIRASAWA* \\ *Nippon Chemical Co., Ltd. (9-11-1, Kameido, Koto-ku, Tokyo 136-8515) \\ ** School of Science and Engineering, Waseda University (3-4-1, Ohkubo, Shinjyuku-ku, Tokyo 169-8555)
}

\begin{abstract}
In this study, $\mathrm{Ni}^{2+}$ removal from electroless nickel plating wastewater (A.co., Ltd.) by reduction crystallization was investigated, to make clear the effect of seeds specific surface area on the $\mathrm{Ni}^{2+}$ removal characteristics. Although the main reaction in this research is the same as the one in electroless nickel plating, the authors have proposed reduction crystallization in which wastewater from electroless nickel plating contacts with suspended nickel powder, to remove and recover $\mathrm{Ni}^{2+}$. The results could be obtained on the relationship between the $\mathrm{pH}$ change profile and recovery efficiency in the reaction process, in which nickel powders having various specific surface area were used as seeds. Experimental results were discussed, considering surface conditions of grown nickel and the behavior of produced fines. With a constant $10 \% \mathrm{NaOH}$ solution feed rate, the $\mathrm{pH}$ profile changed in the process of $\mathrm{Ni}^{2+}$ reduction, by changing the specific surface area of seeds, which means that $\mathrm{Ni}^{2+}$ removal efficiency was affected by the specific surface area of seeds. When constant $\mathrm{pH} 7$ was maintained, higher removal efficiency $\left(0.99 ; \mathrm{Ni}^{2+}\right.$ concentration in the treated water $2.5 \times 10^{-2} \mathrm{~g} \cdot \mathrm{dm}^{-3}$ ) could be obtained, although the specific surface area of Ni seed powder varied. Specific surface of seeds, based on the roughness of seed crystal, was suggested to be an effective factor on the Ni metal coating behavior on the seed surface and also the phenomena of fines production in the process of Ni deposition.
\end{abstract}

Key Words : Electroless Nickel Plating, Wastewater, $\mathrm{Ni}^{2+}$ Recovery, Nickel Powder, Specific Surface Area

\section{1. 緒 言}

1996 年のロンドンダンピング条約の施行にともない, 無 電解ニッケルめっき老化液の海洋投棄が禁止となるなど, 化 学物質や産業廃棄物に対する規制が強化される傾向にある1)。 また，業界の内外を問わず ISO 14000 シリーズの取得への機 運が高まっており, 代替原料への移行, 物質循環を意識した 生産プロセスの要求がある。

こうした背景から, 本業界においても, 老化液の新しい処 理技術が検討されている。一例としては, 老化液にシュウ酸 を加えてシュウ酸ニッケルの形でニッケルを回収後, 水酸化 カルシウムを加えてキルンで焼成することにより, リン酸カ ルシウムと硫酸ナトリウムとを回収する処理技術の提案がな されている。これは, 処理液を無害化して放流することを目 的としているが, 最終処理液のリン濃度が規制基準值を超え ていることや, 添加剤, 錯化剤などに由来した有機物の処理 が課題となっている2)。

本研究では, 資源の有効利用および水処理の負荷を低減す
る意味において, 物質回収に着目し, 環境分野に適用しうる 晶析工学の概念である, 環境晶析 ${ }^{3)}$ に基づいためつき老化液 の新規な処理プロセスの検討を行っている。筆者らの既往研 究では，実際に排出されるめつき老化液を用い，液中におけ る有価金属成分である， $\mathrm{Ni}^{2+}$ を除去・回収する方法として， 老化液を還元剤の存在下で懸濁したニッケル粉と接触させる 還元晶析法 ${ }^{4) ~ 6)}$ を提案し, $\mathrm{Ni}^{2+}$ 除去の最適条件，および回 収したニッケルが再利用できるかを検討した。そこでは，種 晶となるニッケル粉を繰り返し使用して回分処理試験を行っ た。その結果, 回分試験を繰り返すにつれて $\mathrm{Ni}^{2+}$ 回収率が 低下し, 還元晶析効率の低下が確認された。原因として, 回 数の増加につれ $\mathrm{pH}$ の低い時点で反応が始まっており, $\mathrm{H}_{2}$ $\mathrm{PO}_{2}{ }^{-}$の還元力の弱い酸性側で反応が進み, 水素ガスの還元 生成のみに還元剤が消費されたと考えた。なお，これにとも ない, SEM 写真からは微小核の形成と凝集現象が確認され, このため比表面積増大により反応活性面が増したことから， 低 $\mathrm{pH}$ での初期反応性が高まったと考えた7)。

また, 神戸らの研究でも, 無機あるいは有機粉体を基材種 
晶とした場合，急激な反応が生じることが報告されている ${ }^{8)}$ 。 さらに，川上らは，比表面積の大きな粉体を用いることによ り, 所望の膜厚 (粒成長)のニッケルを析出・晶析させるプロ セスについて, 提案している9 。

本研究では, 老化液を懸濁状態にあるニッケル粉と, 還元 状態で接触させるに際して, 比表面積の異なるニッケル粉末 を用いて試験を行うとともに, $\mathrm{pH}$ の操作法を変化させ，そ の過程において, $\mathrm{Ni}^{2+}$ 除去率の相違, および実験前後の回 収ニッケル粉の性状変化について，考察を行った。

\section{2. 理 論}

\section{1 ニッケルめっき老化液の組成}

めっき浴のフォーミュレート例は多岐にわたっており ${ }^{10)}$, めつき浴として使用後に排出される老化液は, 多種多様であ る。めつき浴は 4 〜 6 ターン程度使用されるが, めつきの進 行とともに硫酸ニッケルと次亜リン酸ナトリウムが補充され， 水酸化ナトリウムで $\mathrm{pH}$ 調整されるので, ターン数の増加に ともない, 亜リン酸ナトリウムと硫酸ナトリウムが相当多量 に蓄積してくる。また, $\mathrm{pH} 4$ 〜 5 で $\mathrm{Ni}^{2+}$ が沈殿しないよ うにめっき浴には錯化剤や $\mathrm{pH}$ 緩衝剂である有機酸が使用さ れ，これに加えて微量の安定剂や光沢剤が添加されているの で，老化液は複雑な組成となっており，単純な処理で有効な 結果を得ることが難しい。ここでは，ニッケルの微粉末であ る種晶を老化液に懸濁させることによって, 多様な組成に左 右されない有効な $\mathrm{Ni}^{2+}$ 回収ができると考えた。

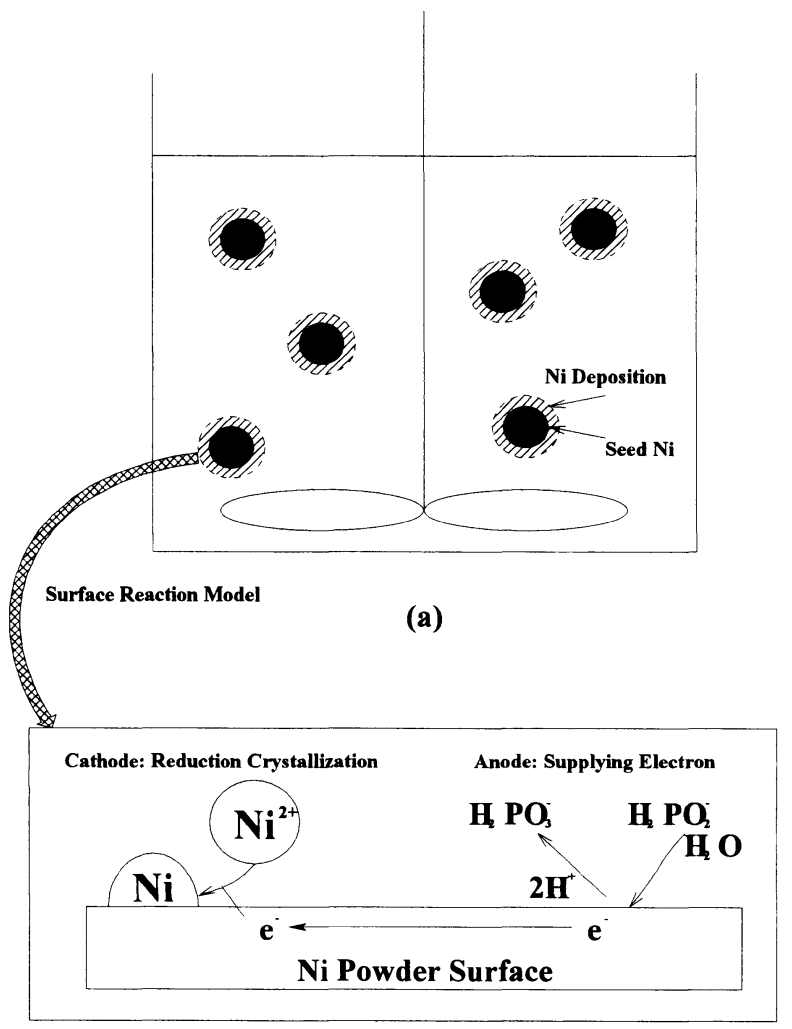

(b)

Fig. 1 Schematic illustration of reduction crystallization method : a, Suspended crystals and b, Reaction on the surface of seed Ni powder.

\section{2 還元晶析による $\mathrm{Ni}^{2+}$ 回収}

無電解ニッケルめつき浴中の基本反応を以下に示す ${ }^{10), 11)}$ 。

$$
\mathrm{Ni}^{2+}+\mathrm{H}_{2} \mathrm{PO}_{2}{ }^{-}+\mathrm{H}_{2} \mathrm{O} \rightarrow \mathrm{Ni}+\mathrm{H}_{2} \mathrm{PO}_{3}{ }^{-}+2 \mathrm{H}^{+} \cdots \cdots(1)
$$

$\mathrm{H}_{2} \mathrm{PO}_{2}{ }^{-}+\mathrm{H}_{2} \mathrm{O} \rightarrow \mathrm{H}_{2} \mathrm{PO}_{3}{ }^{-}+\mathrm{H}_{2} \uparrow \ldots \cdots \cdots \cdots \cdots \cdots \cdots \cdots(2)$

Eq.(1)の反応では，析出したニッケルが自ら触媒として働 いて，連続的な反応晶析を促進させるが，Eq.(2)の反応は次 严リン酸が $\mathrm{Ni}^{2+}$ の還元剤として有効利用されず，加水分解 するので $\mathrm{Ni}^{2+}$ の回収にとって好ましくない反応である。反 応媒体として被めつき基材を浴内に浸漬または懸濁させるこ とで Eq.(1)の反応が基材表面で起こり，ニッケル微小核が発 生・成長析出する。核発生と成長の制御因子は $\mathrm{pH}$ であり, $\mathrm{pH}$ が高くなると $\mathrm{Ni}^{2+}$ の還元反応速度が増す。ただし, $\mathrm{pH}$ が上がりすぎると $\mathrm{H}_{2} \mathrm{PO}_{2}{ }^{-}$の加水分解反応が早くなり, Eq. (2)の反応が支配的となる。また，Eq.(1)の反応晶析が進むと， $\mathrm{H}^{+}$の生成により系内の $\mathrm{pH}$ が低下して $\mathrm{H}_{2} \mathrm{PO}_{2}{ }^{-}$の還元反応 速度が低下する。一般的に酸性浴の還元効率は $30 \%$ 程度で あると言われているが，上記反応機構から $\mathrm{pH}$ によ大きく 異なることが報告されている12)。

本研究では, 既存の無電解ニッケルめつきの概念をふまえ た上で, ニッケル粉を懸濁状態にして, 老化液と接触させ, その表面で還元反応を進行，すなわちニッケル金属を晶析さ せる方法を提案した。本プロセスの概念図を図 1 に示す。

\section{3. 実験方法}

実験装置図を図 2 に示す。 $1.0 \mathrm{dm}^{3}$ ガラスビーカーにあら かじめ $\mathrm{A}$ 社めっき老化液 $0.5 \mathrm{dm}^{3}$ を入れ, テフロン®製パド ル式 2 枚羽根かく汼翼 (翼径 $8.0 \times 10^{-2} \mathrm{~m}$ ) および $\mathrm{pH}$ ガラス 電極とともに恒温槽にセットした。恒温槽で $353 \mathrm{~K}$ まで昇温 した後, 比表面積の異なるニッケル種晶を $10 \mathrm{~g}$ 添加し, か く找回転数 $150 \mathrm{~min}^{-1}$ で分散させた。なお， $\mathrm{pH}$ 調整に関し ては, 以下の 2 方法で行った。

第一の方法(方法 1 ) として，10\%水酸化ナトリウム溶液の 供給速度を一定として行った。ニッケル粉(種晶)添加 $5 \mathrm{~min}$ 後に一定の供給速度 $4.0 \times 10^{-3} \mathrm{dm}^{3} \cdot \mathrm{min}^{-1}$ で，10\%水酸化ナ トリウム溶液 $1.17 \times 10^{-1} \mathrm{dm}^{3}(130 \mathrm{~g})$ の注入を開始した。そ の後, それぞれの条件下での $\mathrm{pH}$ の経時変化を調べ，滴下終 了後の水素ガス発生 (反応 Eq.(2)) の様子を観察した。

他の方法(方法 2 ) として，353K まで老化液を昇温させ， 10\%水酸化ナトリウムを添加し, $\mathrm{pH}$ を 7 に維持しつつ,

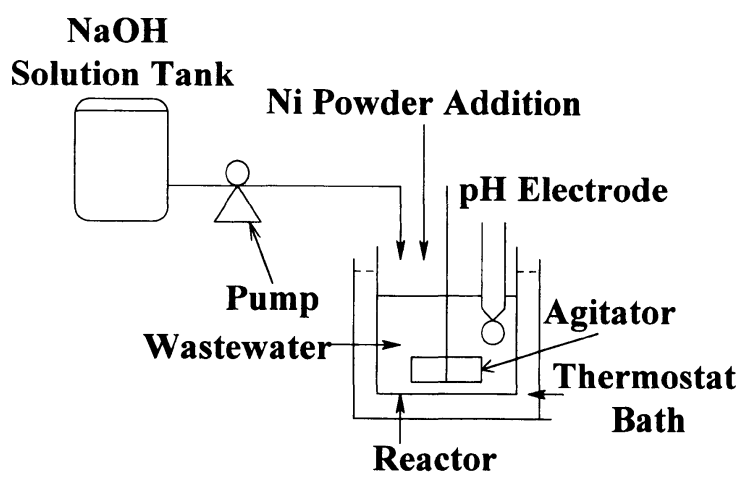

Fig. 2 Experimental Apparatus. 
ニッケル粉 $10 \mathrm{~g}$ を添加した。反応中は $\mathrm{pH}$ の低下を抑制す べく, $10 \%$ 水酸化ナトリウムを添加して, pH 7 を保持した。 方法 1，2 に扔いては，10\%水酸化ナトリウムの供給は, 供給開始後約 $30 \mathrm{~min}$ で終了し, $\mathrm{pH}$ 值がほぼ一定に収束し て(反応 Eq.(1)の終点) 水素ガスの発生も治まり, 熟成を含め $90 \mathrm{~min}$ 経過した時点で装置を止めた。実験終了後, ビー カーを恒温槽から取り出し, 約 $323 \mathrm{~K}$ まで冷却後, ブフナー ロートを用いて減圧ろ過分離した。ろ過分離後の結晶は 323 $\mathrm{K}$ 一定で $24 \mathrm{~h}$ 乾燥し, SEM 写真による性状観察を行った。 なお, それぞれの種晶に関しても, あらかじめSEM 写真観 察および BET 比表面積測定装置で比表面積を測定した。

また, ろ過分離後の母液中に残存する $\mathrm{Ni}^{2+}$ 濃度 (処理液 $\mathrm{Ni}^{2+}$ 濃度) $\mathrm{ICP}$ 発光分光分析装置で測定した。これによ り老化液中に含まれた $\mathrm{Ni}^{2+}$ が, どの程度除去されるかを算 出した。

\section{4. 結果および考察}

\section{4. $1 \mathbf{N i}^{2+}$ の除去・回収特性}

$10 \%$ 水酸化ナトリウム溶液の供給速度を一定とした場合の, 実験開始時間からの $\mathrm{pH}$ の経時変化を図 3 に示す。これによ り, 比表面積の小さい種晶 $\left(0.05 \mathrm{~m}^{2} \cdot \mathrm{g}^{-1}\right)$ ほど反応時の $\mathrm{pH}$ が高く維持され，このことが $\mathrm{H}_{2} \mathrm{PO}_{2}{ }^{-}$の還元効率を増加さ せ,この結果, $\mathrm{Ni}^{2+}$ の回収反応が進むものと推察される。 なお, 比表面積が $1.48 \mathrm{~m}^{2} \cdot \mathrm{g}^{-1}$ の種晶に関しては, 添加直後 から水素ガスの発生が観察された。これにともなって，10\% 水酸化ナトリウム溶液滴下開始までの $5 \mathrm{~min} の$ 間に $\mathrm{pH}$ が 低下し, 図 3 に見られるように, 反応初期の $\mathrm{pH}$ が低下した。 $\mathrm{pH}$ の低い時点では, 加水分解のみに還元剤が消費されるお それがあることが示唆された。

さらに, pHを 7 に保持して行った実験結果と合わせて, 種晶の比表面積に対する回収量を Eq.(3)より算出した。ここ では, 液中で除去された $\mathrm{Ni}^{2+}$ はすべて, ニッケル金属とし て回収できたと考えた。なお， $\mathrm{w}_{0}$ : 処理老化液中の $\mathrm{Ni}^{2+}$ 量, $\mathrm{W}_{1}$ : 処理後の $\mathrm{Ni}^{2+}$ 回収量, $\mathrm{C}_{0}$ : 老化液中の $\mathrm{Ni}^{2+}$ 濃度, $\mathrm{C}_{1}$ : 母液中の残存 $\mathrm{Ni}^{2+}$ 濃度, $\mathrm{V}_{0}$ : 処理老化液量, $\mathrm{V}_{1}$ : 処理 後母液量であり, $\mathrm{C}_{0}=4.6 \mathrm{~g} \cdot \mathrm{dm}^{-3}, \mathrm{~V}_{0}=0.5 \mathrm{dm}^{3}, \mathrm{w}_{0}=2.3$

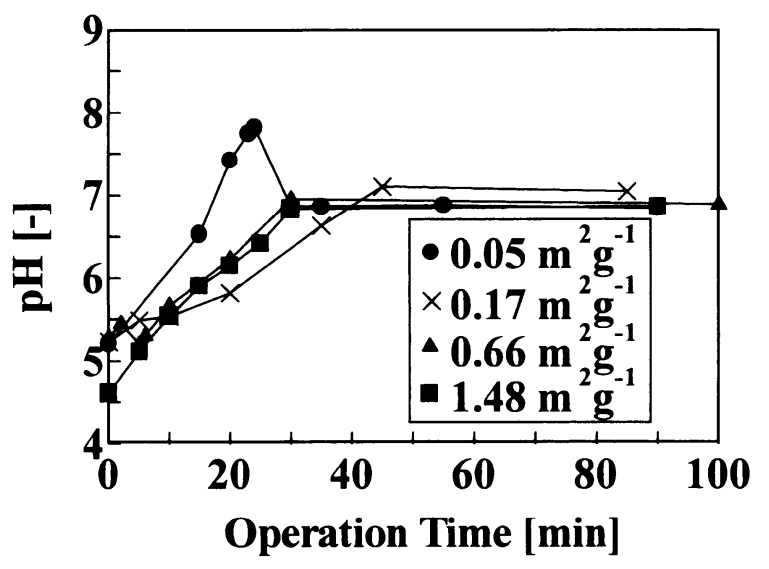

Fig. 3 pH change against the operation time in case of using seed $\mathrm{Ni}$ powder having various specific surface area under constant $10 \% \mathrm{NaOH}$ addition rate. $\mathrm{g}$ として, 変数となる $\mathrm{C}_{1}, \mathrm{~V}_{1}, \mathrm{w}_{1}$ (各実験デー夕)から算出 した。各実験デー夕の值を表 1 に示す。

$$
\mathrm{w}_{1} / \mathrm{w}_{0}=\left(\mathrm{C}_{0} \mathrm{~V}_{0}-\mathrm{C}_{1} \mathrm{~V}_{1}\right) / \mathrm{C}_{0} \mathrm{~V}_{0}
$$

$10 \%$ 水酸化ナトリウム溶液の供給速度一定とした方法 1 の 場合における, 種晶の比表面積と $\mathrm{Ni}^{2+}$ 回収割合との関係を 図 4 に示した。両者の関係を直線近似することにより，Eq. (4)の実験式が得られた。

$\mathrm{w}_{1} / \mathrm{w}_{0}=-0.1939 \mathrm{~S}_{\mathrm{s}}+0.9665$

ただし, $\mathrm{S}_{\mathrm{s}}$ : 種晶比表面積とする。

比表面積の増加につれ, $\mathrm{Ni}^{2+}$ の析出割合が直線的に低下 しており, $\mathrm{pH}$ の低い時点での $\mathrm{Ni}^{2+}$ の還元反応が還元剤の 消費を促進したと考える。

同様に方法 2 の結果に関しても図 4 にプロットしたが, pH 7 を一定に保持したことにより, 種晶の比表面積変化に よる $\mathrm{Ni}^{2+}$ 回収割合の差異は見られず,ほぼ 0.99 となり, 処理液の $\mathrm{Ni}^{2+}$ 濃度は $0.1 \mathrm{~g} \cdot \mathrm{dm}^{-3}$ 以下となった。しかしな がら, 対象とする老化液の特性により, $\mathrm{Ni}^{2+}$ の除去特性は 変化することが予想され, 老化液の種類と除去特性について, さらなるデータの入手を必要とする。

\section{4. $2 \mathrm{Ni}^{2+}$ 回収前後の種晶の性状}

種晶および回収した結晶のSEM 写真を図 5〜7に示す。 図 5 が種晶, 図 6 が供給速度一定, 図 7 が $\mathrm{pH} 7$ 一定の場合 における実験後の結晶で, 比表面積がそれぞれ (a)〜 (d)の 順に, $0.05,0.17,0.66,1.48 \mathrm{~m}^{2} \cdot \mathrm{g}^{-1}$ で対応している。

Table 1 Results of calculation for proportion of $\mathrm{Ni}^{2+}$ deposition amounts $\left(\mathrm{w}_{1} / \mathrm{w}_{0}\right)$.

\begin{tabular}{cccccc}
\hline $\mathrm{S}_{\mathrm{s}}$ & method & $\mathrm{C}_{1}$ & $\mathrm{~V}_{1}$ & $\mathrm{w}_{1}$ & $\mathrm{w}_{1} / \mathrm{w}_{0}$ \\
\hline \multirow{2}{*}{0.05} & 1 & 0.05 & 0.41 & 2.28 & 0.991 \\
& 2 & 0.05 & 0.44 & 2.28 & 0.990 \\
\hline 0.17 & 1 & 0.38 & 0.45 & 2.13 & 0.926 \\
& 2 & 0.06 & 0.45 & 2.27 & 0.988 \\
\hline \multirow{2}{*}{0.66} & 1 & 0.63 & 0.46 & 2.01 & 0.874 \\
& 2 & 0.02 & 0.46 & 2.29 & 0.995 \\
\hline \multirow{2}{*}{1.48} & 1 & 1.16 & 0.47 & 1.75 & 0.761 \\
& 2 & 0.05 & 0.47 & 2.28 & 0.990 \\
\hline
\end{tabular}

$\overline{\mathrm{S}_{\mathrm{s}}\left(\mathrm{m}^{2} \cdot \mathrm{g}^{-1}\right) \text {; specific surface area of seed, } \mathrm{C}_{1}\left(\mathrm{~g} \cdot \mathrm{dm}^{-3}\right) \text {; resid- }}$ ual $\mathrm{Ni}^{2+}$ concentration in treated mother liquor, $\mathrm{V}_{1}\left(\mathrm{dm}^{3}\right)$; volume of treated mother liquor, $\mathrm{w}_{0}(\mathrm{~g})$; initial $\mathrm{Ni}^{2+}$ weight in waste water, $\mathrm{w}_{1}(\mathrm{~g})$; depisited $\mathrm{Ni}^{2+}$ weight and $\mathrm{w}_{1} / \mathrm{w}_{0}(-)$; proportion of $\mathrm{Ni}^{2+}$ deposition amounts.

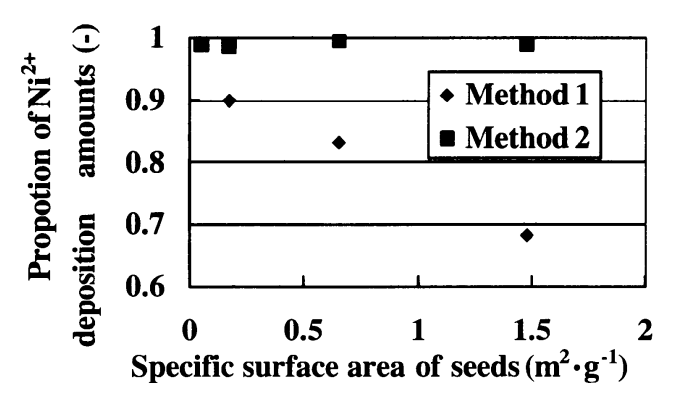

Fig. 4 Characteristics of removal and recovery efficiency of $\mathrm{Ni}^{2+}$ changing specific surface area of seed. 
図 6 では，比表面積 $0.05 \mathrm{~m}^{2} \cdot \mathrm{g}^{-1}$ では，実験後に球状微小 核の生成が認められ，一部凝集が見られるものの，種晶表面 は $\mathrm{Ni}^{2+}$ の析出により被覆されていた。次に, $0.17 \mathrm{~m}^{2} \cdot \mathrm{g}^{-1}$ では, 種晶自体が球形であり, 核発生については, 確認でき なかった。また, 種晶表面も平滑であるので, $\mathrm{Ni}^{2+}$ 析出に よって被覆されたか否かは，判別できなかった。一方，0.66 $\mathrm{m}^{2} \cdot \mathrm{g}^{-1}$ でも, 核発生は観察できないが, 種晶表面の荒れが 消滅し，被覆が進んでいる様子が観察された。さらに，1.48 $\mathrm{m}^{2} \cdot \mathrm{g}^{-1}$ では, 種晶としての 1 次粒子がサブミクロンサイズ の微粒子であることから, 実験時に発生した微小核か否か判 別できなかった。表面では被覆が進行している様子が SEM 写真により確認され，さらに，全体として，凝集が見られた。

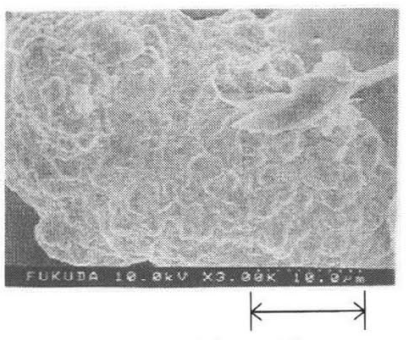

(a) $10 \mu \mathrm{m}$

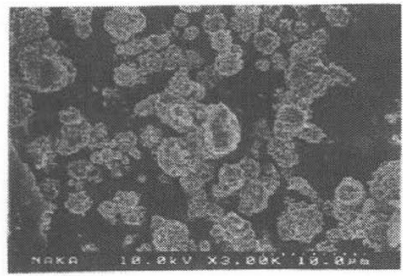

(c)

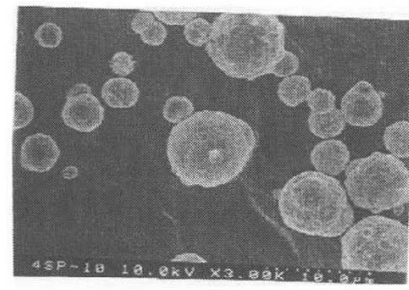

(b)

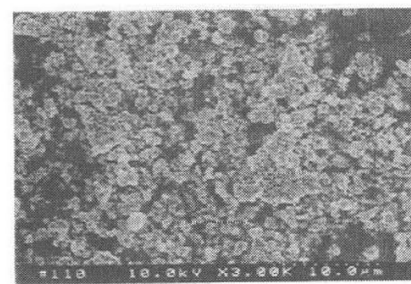

(d)
Fig. 5 SEM photos of seed Ni powder having various specific surface area : a, b, c, d, seed $\mathrm{Ni}$ powder of $0.05,0.17$, $0.66,1.48 \mathrm{~m}^{2} \cdot \mathrm{g}^{-1}$.

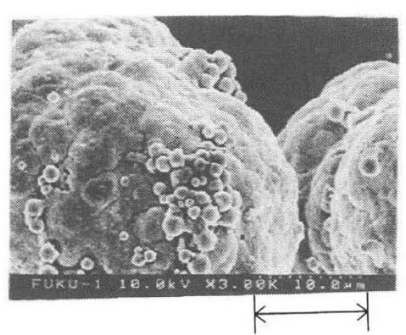

(a) $10 \mu \mathrm{m}$

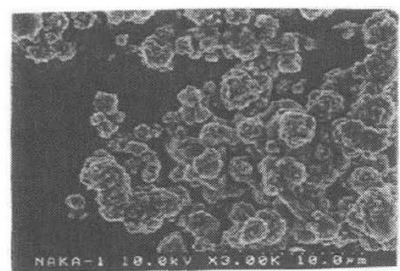

(c)

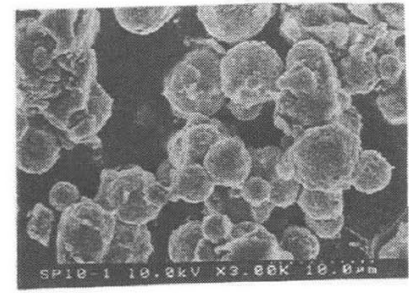

(b)

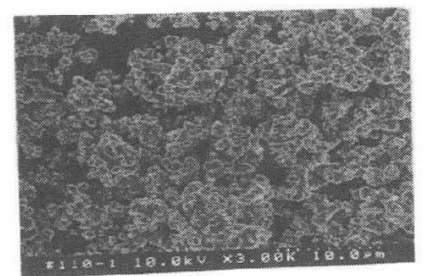

(d)
Fig. 6 SEM photos of recovered Ni powder (Case of $10 \%$ $\mathrm{NaOH}$ feed rate $=4.0 \mathrm{dm}^{3} \cdot \mathrm{min}^{-1}$ constant $): \mathrm{a}, \mathrm{b}, \mathrm{c}, \mathrm{d}$, seed $\mathrm{Ni}$ powder of $0.05,0.17,0.66,1.48 \mathrm{~m}^{2} \cdot \mathrm{g}^{-1}$.
一方, 図7のように, 種品比表面積の小さい $0.05 \mathrm{~m}^{2} \cdot \mathrm{g}^{-1}$, $0.17 \mathrm{~m}^{2} \cdot \mathrm{g}^{-1}$ の場合，(a),(b)に見られるょうに球状の微小核 の生成が観察された。一方, 種晶比表面積が大きくなるにつ れ, (c), (d)に見られるように, 種晶が被覆し, 微小核の生
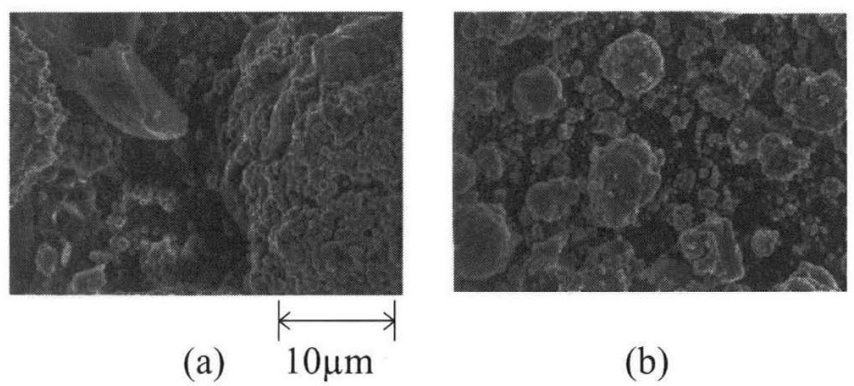

(a)

(b)

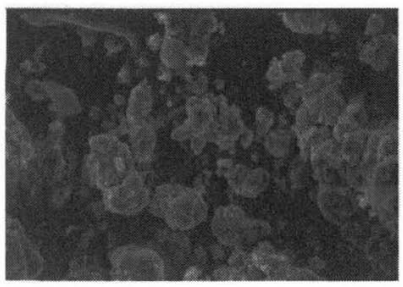

(c)

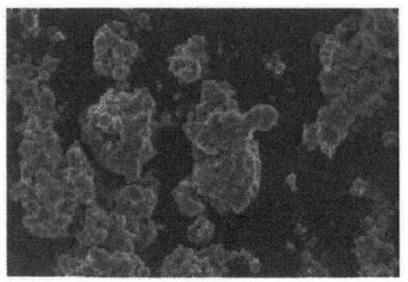

(d)

Fig. 7 SEM photos of recovered Ni powder (Case of $\mathrm{pH}=7.0$ constant) : a, b, c, d, seed Ni powder of $0.05,0.17,0.66$, $1.48 \mathrm{~m}^{2} \cdot \mathrm{g}^{-1}$.
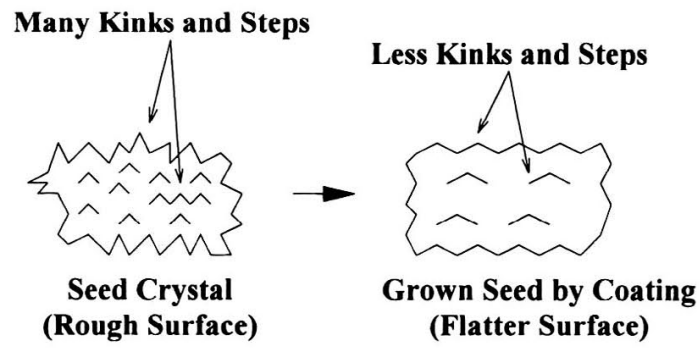

(a)

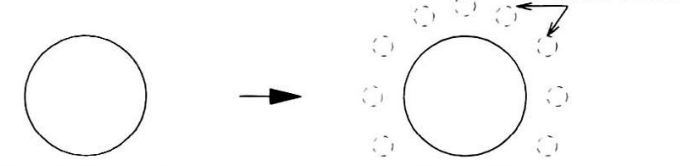

Seed Crystal (Flat Surface)

Production of New Fine (in the Supersaturated Bulk Solution)

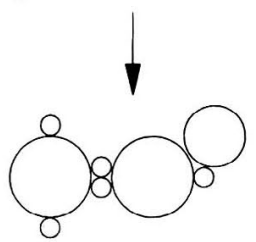

Agglomeration by Produced Fines

(b)

Fig. 8 Schematic illustration showing the characteristics of crystal growth and nucleations: a, case of seed $\mathrm{Ni}$ powder having roughness and $\mathrm{b}$, case of spherical crystal having flat surface. 
成が少ない様子が確認された。これは，比表面積が小さい場 合は，比表面積を決める種晶表面の凹凸が早い段階で被覆さ れ, 残存する $\mathrm{Ni}^{2+}$ が溶液内で核化したと推察される。これ に対し, 比表面積が大きい場合は, 種晶表面の山凸が多いこ とから, $\mathrm{Ni}^{2+}$ 析出分が表面の被覆のみ支配的となり, 微小 核の発生が見られなかったと考える。

前述したように, $\mathrm{pH}$ を 7 として定に制御することによ り, $\mathrm{Ni}^{2+}$ 析出量が多くなり,このため, 図6,7における 析出の挙動が異なったものと考える。

ここで, 種晶の実験前後の性状変化を表す概念図を図 8 に 示す。

図 8 (a)において, 表面上にデンドライトな突起を有する 結晶の場合, そのローカルなキンク，ステップ部位に扔いて， 結晶表面への被覆成長が支配的に起こると考える。

一方, 図 8 (b)では, 結晶表面が平滑であることから表面 上での反応が起こりにくく, 溶液内からの核発生が支配的と なる。比表面積の小さい種晶を用いた場合, その反応初期で は種晶と微小核がそれぞれ単独で存在しやすいが, 次第に結 晶個数が増え衝突確率が高くなると, 発生核を介して凝集が 起こると考える。

種晶比表面積の小さい方法 1 の場合と方法 2 については, 溶液内から発生したと見られる微小核が発生しており, 図 8 (b)のような反応が起こっていると考える。方法 1 の種晶比 表面積が大きい場合については, $\mathrm{Ni}^{2+}$ の還元晶析が十分に 進行せず, $\mathrm{Ni}^{2+}$ の析出量が少なかったことで, 種晶の全表 面積に対する被覆量が少なくなり, 図 8 (a)の析出状態にと どまったと考える。

\section{5. 結言}

本研究では, 組成が複雑である無電解ニッケルめつき老化 液について, ニッケルの微粉末である種晶を老化液に懸濁さ せることにより，液中の $\mathrm{Ni}^{2+}$ を回収する実験的な検討を 行った。

無電解ニッケルめつき老化液 (A 社) からの還元晶析法に よる $\mathrm{Ni}^{2+}$ 回収について, 比表面積の異なるニッケル粉末を 用いて, $\mathrm{pH}$ 調整の操作法を変え, $\mathrm{Ni}^{2+}$ 除去・回収特性の相 違, さらに実験前後の回収ニッケル粉の性状変化について, 考察を行った。

$10 \%$ 水酸化ナトリウム溶液の供給速度を一定とした場合,
$\mathrm{Ni}^{2+}$ 回収割合については, 種晶の比表面積の増加につれ, $\mathrm{Ni}^{2+}$ の析出割合が直線的に低下しており，その関係が直線 近似された。また, 比表面積の小さい種晶 $\left(0.05 \mathrm{~m}^{2} \cdot \mathrm{g}^{-1}\right)$ ほ ど反応時の $\mathrm{pH}$ が高く, $\mathrm{Ni}^{2+}$ の還元反応速度が増すので, $\mathrm{Ni}^{2+}$ の回収が促進された。一方, 比表面積が $1.48 \mathrm{~m}^{2} \cdot \mathrm{g}^{-1}$ の種晶に関しては, 反応初期の $\mathrm{pH}$ が低下し, $\mathrm{pH}$ の低いま ま反応が進行したことで, 水素ガスの生成に, より多くの還 元剤が消費されたものと考えた。

$\mathrm{pH}$ を 7 と一定に保持した場合, 種晶の比表面積変化によ る $\mathrm{Ni}^{2+}$ 回収割合の差異は見られず,ほぼ 0.99 となり, 処 理液の $\mathrm{Ni}^{2+}$ 濃度は $25 \mathrm{mg} \cdot \mathrm{dm}^{-3}$ となった。結晶表面の $\mathrm{SEM}$ 写真観察の結果, 種晶表面の凹凸状態は, $\mathrm{Ni}^{2+}$ の析出にと もなう表面の被覆と微小核の発生に支配的な因子となること が示唆された。

なお本研究の一部に関し, 表面技術協会第 102 回講演大会 において, 発表を行った。

(Received February 27, 2001 ; Accepted December 25, 2001)

\section{文献}

1 ）新子保徳；表面技術協会・めっき技術部会 11 月例会テキス ト, p. 1 (1995)

2 ）全国めつき工業組合連合会編集；現代のめつき技術，通産省 主催ブロック別研修会テキスト, p. 68 (1997)

3 ) I. Hirasawa ; Proc. the 8 th APPChE Congress in Korea, p. $1565-1568$ (1999)

4) K. Horikawa, I. Hirasawa ; Proc. 5 th International Symposium on Separation Technology between Korea and Japan, p. 359-362 (1999)

5 ）堀川 健, 平沢 泉; 第 32 回化学工学会秋季大会要旨集, B 308 (1999)

6 ) K. Horikawa, I. Hirasawa ; The Korean Journal of Chemical Engineering, 17(6), 629-632 (2000)

7 ) 堀川 健, 平沢 泉; 第 33 回化学工学会秋季大会要旨集, p. $116(2000)$

8 ）神戸徳蔵, 熊谷八百三, 尾形幹夫, 越崎直人, 杉原秀樹; 製品科 学研究所研究報告, 121, p. 1-30 (1991)

9 ）川上 浩, 竹下淳一; 表面技術, 42, 308 (1991)

10）神戸徳蔵；無電解めつき, p. 1-6, 14 (槙書店, 1984), 改訂版 (橫書店, 2000)

11）林 忠夫, 松岡政夫, 縄舟秀美 ; 無電解めっき一基礎と応用, p. 1-30（日刊工業新聞社, 1994）

12）田代雄彦; 表面技術, 50，140（1999） 